\title{
Problems and development trends of coal transportation infrastructure in Russia
}

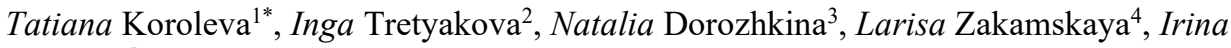 \\ Sovenko ${ }^{5}$
}

1,2,3,4 T.F. Gorbachev Kuzbass State Technical University, Department of Management Accounting and Analysis, 650000 Kemerovo, 28 Vesennya st., the Russian Federation

${ }^{5}$ Joint-stock company SUEK-Kuzbass, 652507, Leninsk-Kuznetsky, 1 Vasilyeva st., the Russian Federation

\begin{abstract}
Analysis of the trends in the coal industry in Russia showed that, despite the stable demand in the global coal market, the growth rate of coal exports is slowing down. The main reason is the shortcomings of the transport and logistics infrastructure for the coal haulage. At the same time, the countries of the Asia-Pacific region are a promising export destination, and it is the Eastern operating domain of the Russian railway network that is most loaded and has insufficient throughput capacity. The study of the elements of the transport and logistics infrastructure revealed key problems, namely the underdevelopment of the railway infrastructure, the inconsistency of development programs for coal mining regions, port facilities and railway infrastructure, and the inconsistency of the operation of ports and the railway. Due to the fact that the development of the railway network in the eastern direction is a long-term project, and the coal haulage values will not be increased in the near future, an assessment is made of the possibility and economic efficiency of reorienting freight traffic in other directions.
\end{abstract}

\section{Introduction}

In modern conditions of instability of the world coal market, the search for solutions to the problems of coal transporting from the place of production to the western and eastern ports of the Russian Federation is becoming increasingly important. Analysis of publications on the prospective development of coal-fired generation, the state of the world energy market and forecasts of demand for coal allows drawing conclusions about maintaining demand at a sufficiently high level, as well as maintaining the capacities of the world coal-fired generation. According to forecasts of primary energy consumption, the share of coal-fired generation will amount to $26 \%$ by 2040 . Despite the trend towards a decrease in the energy intensity of GDP and a decrease in the rate of GDP growth, leading world analysts predict an increase in demand for coal by 2040 to 9 billion tons [1-4].

At the same time, Russia extracts about $4.5 \%$ of all coal, and the share of Russian coal in the world export structure is more than 15\%, ranking third after Australia and Indonesia.

\footnotetext{
${ }^{*}$ Corresponding author: ktg.eogp@kuzstu.ru
} 
At the same time, the main obstacle to increasing the export of Russian coal is not so much the situation on the world market as the throughput capacity of the main coal carrier Russian railways. Thus, the issues of efficient transportation of coal to the consumer remain relevant. The problem is complicated by the remoteness of the main coal basins of the Russian Federation from the border crossings, both in the west and in the east of the country. Thus, the issues of efficient delivery of coal to the consumer remain relevant. The problem is complicated by the remoteness of the main coal basins of the Russian Federation from the border crossings, both in the west and in the east of the country.

\section{Theory of Experimental Research}

The transport and logistics infrastructure for coal transportation is a system of infrastructure elements, vehicles, transport and logistics companies and government regulations that ensure the efficient coal haulage. The main elements are transport companies, coal transshipment terminals, specialized operator companies, port coal terminals. The main mode of transport for coal haulage on the territory of the Russian Federation is currently railway transport. Coal is the main cargo transported by Russian railways. Its share in freight turnover is $43.9 \%$, with more than $90 \%$ concentrated on the West Siberian, Krasnoyarsk, East Siberian and Far Eastern railways. The export component of transportation in $2019-2020$ exceeds $55 \%$ of the total coal freight turnover [5]. In the northwest direction, coal is exported through the ports of Murmansk, Yeisk and Ust-Luga, in the southeast direction - through the ports of Vanino and Vostochny.

Coal is a bulk but low-income rail cargo. The actual freight rates actually guarantee the unprofitability of the coal mining process for the customer of transport services - the coal mining company, since they increase the price of coal by more than 2 times. For 10 years, the permanent negotiation process has ensured a decrease in coal freight rates, which allows Kuzbass coal to remain competitive in the world market. The distance of coal transportation from Kemerovo to domestic ports of the Far East, North-West and South differs by 20\%, and the average cost of coal transportation - by 3-5\% [6-8].

The reduction in freight rates, on the one hand, makes transportation unprofitable for the carrier represented by Russian Railways, on the other hand, increases the demand from coal producers for services and ensures the maximum load of railways. Therefore, a prerequisite for the efficiency of transportation for a carrier is a block train shipment, which is the basis for rate-setting. For coal, the block train is $60-65$ wagons, that is, the shipped consignment is about 4.5-4.8 thousand tons. This is the daily coal production for an average coal mining enterprise. In this regard, in order to ensure the full shipment of coal to the consumer, the block train shipment should be almost daily.

Kuzbass is the leader in coal transportation by rail. Kuzbass enterprises mine $60 \%$ of all coal in the Russian Federation and provide $70 \%$ of all coal exports. The remoteness of a deposit from coal terminals leads to a significant rise in the cost of the mineral. Transportation costs in the price of coal are about $50 \%$, while freight and port dues account for about $8 \%$ more $[9,10]$. The average cost of transporting coal from Kuzbass to the port of Vanino is 1860 rubles per ton, that is, about 140 thousand rubles per wagon.

The pandemic of the new coronavirus infection COVID-19 has affected all sectors of the economy, not bypassing the coal industry. Coal production in Russia at the end of 2020 decreased by $9.7 \%$ and amounted to 401.4 million tons, and in Kuzbass - by $11.8 \%$ and amounted to 220.7 million tons. This was reflected in a corresponding way on the rail transportation dynamics. The volumes of coal loading and transportation through the Russian Railways network in 2020 decreased by 5\%, including by $4 \%$ in export directions. Despite this, according to WoodMackenzie's estimates, coal exports from Russia by 2030 
could grow by almost 30\%, and the Program for the Development of the Russian Coal Industry for the period up to 2035 envisages an increase in production volumes up to 459 million tons by 2025; and for Kuzbass the volume of 300 million tons was determined, which was supposed to be produced already in 2020 [11]. On March 2, 2021, at a conference call on the development of the country's coal industry, President of the Russian Federation V.V. Putin set the task to increase the volume of coal shipments eastward by $30 \%$ by 2024 . However, an increase in the volume of transportation of Kuzbass coal is possible only if the freight rates are increased by 2.4 times, which will ensure the profitability of these services for the carrier. Russian Railways has already warned that with the addition of 5 million tons of Kuzbass coal at the Eastern operating domain, the loss of income from the inability to export more highly profitable cargo will amount to 6 billion rubles. At present, the level of unprofitable transportation of Kuzbass coal to the port of Vanino is $226 \%, 37 \%$ of the throughput capacity at the approaches to the eastern ports and more than $54 \%$ of the throughput capacity at the exit from Kuzbass are reserved. Therefore, according to the agreement signed between the carrier and the government of Kuzbass in 2021, the coal export rate in the amount of 53 million tons is maintained.

The largest coal terminals in the country are owned by coal companies. At the same time, the market is quite concentrated: the 10 largest terminals handle about $70 \%$ of transshipment. However, the remaining $30 \%$ is accounted for by smaller terminals. Almost $50 \%$ of coal transshipment is provided by two terminals owned by JSC UK Kuzbassrazrezugol. These are terminals in the ports of Vostochny and Ust-Luga. Another $20 \%$ of coal are transshipped at the terminals of JSC SUEK in the ports of Vanino and Murmansk. In 2019-2020 new terminals were put in operation: the Vostochny Port terminals with a capacity of almost 50 million tons of coal per year and Porta Vera with a capacity of 5 million tons and the prospect of increasing to 10 million tons in the Far East, the OTEKO terminal with a throughput capacity of 25 million tons in the South. Reduced demand for coal and decreasing prices on the European market led to a slowdown in investment and the termination of a number of projects for the construction of new terminals in the Baltic [12].

The construction of new terminals and an increase in the throughput capacity of those operating in Primorye and in the port of Vanino are expected in the near future, which will ensure the total capacity of terminals in the Far East direction up to 220 million tons. This means that, in the near future, the risk of a shortage of coal terminals is minimal.

As for the rolling stock, in the period 2015-2018, the problem with wagons has been practically resolved due to both its own fleet and the development of specialized operator companies to provide services for renting wagons and open wagons. Thus, the main problems of coal transporting are:

- underdeveloped railway infrastructure;

- inconsistency of development programs for coal mining regions, port facilities and railway infrastructure;

- inconsistency of the operation of ports and the railway;

- poor structuredness of traffic, despite the introduction of digital logistics technologies;

- shortcomings in the organization of loading and unloading operations in coal terminals.

Therefore, in the face of a lack of own investment in infrastructure development, an increase in demand from coal mining companies, taking into account the importance of the coal industry for the country's economy, creates the preconditions for the state's participation in financing the expansion of transportation opportunities in the East. The adopted development strategy of JSC Russian Railways provides for an increase in the carrying capacity of the railway in the direction of ports and border crossings of the Far East to 125 million tons in 2020-2021 and the further development of infrastructure 
provides for an increase in this indicator to 185 million tons by 2024-2025. However, these measures will not be able to fully meet the demand for freight.

\section{Results and Discussion}

The forecasts for the development of the world economy indicate that China and India continue to be the most promising destinations for the export of Russian coal. At the same time, the total freight costs for the delivery of Russian coal to consumers in the Asian markets already reach $\$ 40-45$ per ton, while prices in the Asian markets in 2020 dropped to $\$ 70$ per ton (in Europe - to \$ 57). In this situation, the prospects for the abolition of the freight rate reduction coefficient according the distance of transportation, as well as the long-term nature of the increase in the carrying capacity of the railways of Siberia and the Far East, necessitate to search for new resources of transport and logistics infrastructure developments. At the same time, Russian Railways, in the face of a surplus of throughput in the southern and north-western directions, proposes to reorient coal flows $[13,14]$.

Currently, there are three directions for the development of transport and logistics infrastructure. The first direction is the Northern Sea Route "Tyumen - Sabetta - Sea Port of China". This direction makes it possible to reduce the length of the route by 5.2 thousand $\mathrm{km}$, reduce costs by 3.5 million dollars and support transit by feeder routes. To unleash the potential of the port of Sabetta on the territory of the Yamalo-Nenets Autonomous Okrug, a large infrastructure project "Northern Latitudinal Passage" is being implemented. In the future it will make it possible to bring the railway to the universal port of Sabetta on the Yamal Peninsula, thereby providing access to the unified transport system of Russia to the Arctic infrastructure, connecting it with the Northern Sea Route. At the moment Kuzbass Tyumen - Korotchaevo is the least loaded section of the highway, moreover, it is doubletracked almost throughout. The Kuzbass - Tyumen - Novy Urengoy relief is flat almost throughout the entire length, which allows driving heavy trains providing the possibility of increasing the capacity of the route. The only obstacle to using this direction is the lack of a coal terminal, which should provide for drying coal to eliminate freezing and restore quality.

Another development direction is projects for the construction of two highways Arkhangelsk - Syktyvkar - Perm (Solikamsk) ("Belkomur") and Sosnogorsk - Indiga ("Barentskomur"). These projects are included in the list of measures for the development of aviation and railway infrastructure to ensure the cargo base of the Northern Sea Route, approved by the government of the Russian Federation in December 2019.

The plan was formed based on the forecast of all existing and prospective cargo flows, it included 84 events. The modernization, expansion of the main infrastructure and the implementation of additional measures are envisaged.

Belkomur (White Sea - Komi - Ural) is a complex project of industrial and infrastructural development of the North of the Russian Federation and the Urals, the basis of which is the construction of the Solikamsk - Syktyvkar - Arkhangelsk railway line with a length of $1161 \mathrm{~km}$. Its throughput capacity will be up to 35 million tons of cargo per year. The railway consists of 2 sections, the Northern one (through the territory of the Arkhangelsk region and Komi) and the Southern one (from Syktyvkar through the territory of Komi and the Perm Territory). In fact, it is necessary to lay the Karpogory - Vendinga and Syktyvkar - Gainy - Solikamsk lines, and the remaining sections of the Northern Railway (a branch of Russian Railways) should be reconstructed. In February 2019, Gazprombank, the governments of Komi, the Arkhangelsk region and the interregional company Belkomur, within the framework of the Russian Investment Forum in Sochi, signed an agreement on cooperation on the construction of the Arkhangelsk - Syktyvkar - 
Solikamsk railway. The implementation of the project will allow not only to reduce the transit route by $800 \mathrm{~km}$, but also to reduce the cost of transportation by $50 \%$. The Barentskomur project (Barents Sea - Komi - Ural) involves the creation of a railway along the route Surgut (Khanty-Mansi Autonomous Okrug) - Polunochnoe (Sverdlovsk Region) Troitsko-Pechorsk - Sosnogorsk - Indiga.

The third direction is the Northern Dimension, which provides access through Arkhangelsk and Murmansk to European ports and access to the Northern Sea Route. And if access to the ports of Europe is not relevant now, in the absence of a terminal in Sabatta, this direction allows to ensure the delivery of coal to consumers in the Asia-Pacific region through the North.

\section{Conclusion}

As a result of the conducted research, it was concluded that it is necessary to search for new and develop existing directions of coal transportation. The most promising direction is the Kuzbass-Murmansk-Ports of China route, since the North-West direction of the Russian railway network is the least loaded, the throughput capacities of coal terminals in Murmansk is quite high. In the long term, it is necessary to increase the coal transportation volumes in the eastern direction while maintaining the freight rate reducing coefficients. The development of the Eastern operating domain will increase the cargo turnover and reduce the financial burden on the carrier. At the same time, in order to reduce the dependence of the Russian coal industry on the transport component, it is necessary to increase the share of deep coal processing and export of high-margin products [15].

\section{References}

1. D.A. Pankov, V.Ya. Afanasiev, O.V. Baikova, Ye.A. Tregubova, Coal, 3(1140), 23 (2021)

2. D.A. Pankov, V.Ya. Afanasiev, Coal, 11(1136), 67 (2020)

3. I.V. Petrov, K.V. Shvandar, D.V. Shvandar, T.F. Burova, Coal, 7(1132), 66 (2020)

4. F.Yu. Filimonov, MGIMO Review of International Relations, 6, 228 (2020)

5. Barack O, Powering Empire: How Coal Made the Middle East and Sparked Global Carbonization (University of California Press, 2020)

6. Thurber M, The Global Coal Market: Supplying the Major Fuel for Emerging Economies (Cambridge University Press, 2020)

7. D. Weaving, McCloskey's 4th Annual Russian Coal Conference (St. Petersburg, 2006)

8. T.G. Weyman-Jones, Energy in Europe: Issues and Policies, Routledge Library Editions: Energy Routledge (2019)

9. S.A. Zhironkin et al., IOP Conference Series: Materials Science and Engineering, IOP Publishing, 012127 (2016)

10. F. Masahisa, P. Krugman and A.J. Venables, The spatial economy: Cities, regions, and international trade (MIT Press, Cambridge, 1999)

11. V.G. Mikhailov, T.V. Galanina, Ya.S. Mikhailova, Waste formation and management dynamics in coal mining. Gornyi Zhurnal, 4, 89 (2019)

12. I.V. Kuznetsova, S.S. Timofeeva, IOP Conference Series: Earth and Environmental Science, 408, 012075 (2020) 
13. T.V. Galanina, V.G. Mikhailov, N.N. Golofastova, T.G. Koroleva, IOP Conference Series: Earth and Environmental Science, 50, 012037 (2017)

14. I.A. Ageev, V.N. Burkov, V.I. Zinchenko, T.V. Kiseleva, Structural Analysis of the Time Data Series. Automation and Remote Control, 66, 995 (2005)

15. S.S. Timofeeva, M.A. Murzin, IOP Conference Series: Earth and Environmental Science, 408, 012067 (2020) 